Avner Giladi

\title{
LIMINAL CRAFT, EXCEPTIONAL LAW: PRELIMINARY NOTES ON MIDWIVES IN MEDIEVAL ISLAMIC WRITINGS
}

In this article, the first fruit of an ongoing research on the sociocultural history of midwifery in medieval Muslim societies, I trace the attitudes toward midwives as revealed in Arabic biographical, medical, and legal texts. These texts, the product of male scholars, mirror an ambivalent attitude toward midwives: a mixture of repressed admiration, open repulsion, and fear. Thus, midwives are almost totally absent from Islamic scriptures, and Muslim writers make them play only a minor role in biographical and hagiographic literature, where the midwives of the Prophet's family are consciously or unconsciously "blocked" from becoming mythological figures. Women, sometimes hesitatingly identified as midwives, nevertheless played a role through their very presence at the moment of the Prophet's birth. In a storylike manner, they set an example for the implication of the legal rules concerning the midwife's exceptional status as a witness in court, rules that were formulated and consolidated in the formative period of Islamic law side by side with the traditions on the Prophet Muhammad's birth. 